\title{
The Impact of Training on Employees' Performance: The Case of Banking Sector in Lesotho
}

\author{
Mamofokeng Eliza Motlokoa \\ Department of Business Administration, National University of Lesotho, \\ P.O. Roma 180 Maseru 100, Lesotho. \\ E-mail: emskantsy@gmail.com. \\ Lira Peter Sekantsi (Corresponding Author) \\ Department of Payments and Settlement, Central Bank of Lesotho, \\ P.O. Box 1184, Maseru 100, Lesotho. \\ E-mail: skantsy@gmail.com. \\ Rammuso Paul Monyolo \\ Department of Business Administration, National University of Lesotho, \\ P.O. Roma 180 Maseru 100, Lesotho. \\ E-mail: prmonyolo@gmail.com.
}

Received: Feb. 12, 2018 Accepted: Mar. 1, 2018 Online published: Mar. 13, 2018

doi:10.5296/ijhrs.v8i2.12812 URL: https://doi.org/10.5296/ijhrs.v8i2.12812

\begin{abstract}
Human Resources Management literature regards training as the blood stream of any organization because the success of an organisation to achieve its objectives and goals heavily highly depends on its workforce. For this reason, organizations should invest in employees' training in an effort to enhance their performance and that of an organisation. Nonetheless, some organizations regard training as unnecessary expenditure and always cut training budgets in an effort to improve their financial standing to the detriment of their employees' welfare because that action incapacitate staff to adapt to the ever-changing working environment and uncertain conditions on account of, inter alia, rapid technological innovation and organizational change. This study employed stratified sampling technique to
\end{abstract}


draw a sample of 171 employees from a population of 300 employees through self-administered questionnaire to examine the impact of training on employees' performance, employee's motivation and job-satisfaction in the banking sector in Lesotho. The findings of the study generally revealed that training not only increases employees' performance but also positively affects employees' motivation and job satisfaction within the banking sector in Lesotho. Therefore, the banking sector in Lesotho should regularly allocate resources for employees' training based on identified skill gaps to sharpen employees' skills, knowledge and abilities in order to capacitate them to cope with the ever-changing working environment and uncertain conditions and to improve their motivation and job-satisfaction.

Keywords: training, employee performance, job satisfaction, motivation, banking sector, Lesotho

\section{Introduction}

In recent years, business organizations are characterized by turbulences of organizational change, stiff competition, market globalization and rapid financial innovation resulting from technological advancement. For instance, globalization and financial liberalization have led to huge change in the financial sector worldwide through significant developments in the money and capital markets more especially in developed countries on the one hand. On other hand, financial innovation has significantly changed financial system landscape by introducing new payment, clearing and settlement methods, inter alia, which to a great extent require more training in order to be understood and therefore implemented by the commercial banks. Otherwise, these innovations have potential to introduce new risks to the financial sector, which the commercial banks may not be able to manage and/or mitigate with resultant threat on profitability and business sustainability.

In an effort to guard against these forces and to sustain their existence, maintain and enhance quality of their products and services offering over time, it is necessary, if not imperative, for financial institutions especially the commercial banks to engage in continuous investment in training and development of employees to improve their capabilities and competencies required to perform particular tasks effectively and efficiently in order to achieve organizational goals and objectives. This is because a talented and well-trained workforce is able to cope with dynamic working environment and uncertain conditions within which the commercial banks operate and as well as risks they may face in the future. In this regard, well-trained workforce is a major source of competitive advantage in the competitive global market and in practice banks usually compete largely on getting well-trained human resources to support their business activities (Tahir \& Sajjad, 2003; Becker, et al., 2015).

In line with this, there is a large strand of the empirical studies in the literature that examine the link between employee training and employees' performance and/or organizational performance based on various organizations including commercial banks in different countries. Such studies provide empirical evidence in support of the positive correlation between employee training and employees' performance (e.g. Awang et al., 2010; Tahir \& Sajjad, 2013; Bataineh, 2014; Dabale, 2014; Nan, 2014; Afsana et al., 2016; Athar \& Shah, 2015; Ugbombhe et al., 2016). However, many of these studies predominately cover the 
advanced nations but less developing countries including Lesotho (see Jacobs \&Washington, 2003; Lyons, 2008; Ubeda-Garce et al., 2012). The paucity of the research on this issue in Lesotho creates an interesting gap which needs to be filled because the empirical study, which links these variables in a developing country such as Lesotho, where none of such studies exist, not only has important policy implications regarding the link between training and employees' performance but also has the potential to add a unique variance to the existing literature.

Furthermore, there are some empirical studies in the literature, which established that many organizations (including commercial banks) usually cut training budgets when financial positions are poor and this not only results in brain drain because employees usually leave such organizations in search of greener pastures elsewhere but also consequently increases costs for the organizations (including commercial banks) as they have to find replacement of such employees (see Casio, 1989; Elnaga \& Imran, 2013; Adnan, 2014). This finding is corroborated by a growing concern among the majority of government, international organizations and private sector (including the banking sector) employees in Lesotho, who claim that their organizations seem not to realize the importance of employee training on employees' performance because they generally curtail or squeeze training budgets every year. This situation not only negatively impact on employees' performance as employees must always update their skills, knowledge and competencies in order to cope with the ever-changing working environment, uncertain conditions and changes in technology but also demotivates employees, increases job dissatisfaction and job turnover, and consequently increases the costs of hiring new employees with resultant slowdown in organizational profitability.

Therefore, the present study attempts to fill the existing research vacuum in Lesotho by examining the effect of training on employee performance, motivation and job satisfaction in the banking sector in Lesotho. The main research questions are: what is the effect of training on employee performance? And to what extent does training enhance employees' motivation and job satisfaction? In order to examine the relationship between these variables, this paper employed stratified sampling technique to draw a sample of 171 employees from a population of 300 employees through self-administered questionnaire and used descriptive statistical techniques for data analysis. The empirical findings of the paper indicate that employees' training actually enhances employees' performance, employees' motivation and job satisfaction with resultant potential to improve job-commitment in the banking sector in Lesotho.

Following this introduction, the remainder of the study is organized as follows. Section 2 discusses an overview of the banking sector in Lesotho; section 3 discusses the theoretical and empirical literature. Section 4 presents the research methodology while section 5 presents and analyses the results of the study. Section 6 concludes the study and provides policy recommendations.

\section{Overview of the Banking Sector in Lesotho}

Lesotho has a relatively small banking sector, which consists of four commercial banks; 
namely Standard Lesotho Bank, Nedbank Lesotho and First National Bank and Lesotho Post Bank. Three of these commercial banks - Standard Lesotho Bank, Nedbank and First National Bank - are foreign owned, and subsidiaries of South African banks while the Lesotho Post Bank is the only local bank wholly owned by the Government of Lesotho, established by Ministry of Communications, Science and Technology (Wade Publications, 2015).

Standard Lesotho Bank is the largest bank in Lesotho in terms of assets and market share and its history dates as far back as 1995 when the Standard Bank Group acquired Barclays Bank Plc to form a new entity called Standard Bank Lesotho. However, in 1999, Standard Bank Group and the Government of Lesotho entered into an agreement wherein the former would manage the then Lesotho Bank Limited. Eventually, an agreement was reached to establish a new company that was later known as Lesotho Bank 1999 Limited with the shareholders being Standard Bank Group, Lesotho Unit Trust and the Government of Lesotho. In July 2006, the two banks merged to form Standard Lesotho Bank Limited as it is known today, which is jointly owned by the Government of Lesotho, Lesotho Unit Trust and Standard Bank Group. This bank operates in all the districts of Lesotho with a total of 19 branches in the country and it has a network of automatic teller machines (ATMs) that extends throughout the lowlands and highlands of Lesotho. The bank offers a wide range of solutions for personal and business banking, corporate banking as well as investment banking (Wade Publications, 2017; Standard Lesotho Bank, 2017).

Nedbank Lesotho Limited - a subsidiary of the Nedbank Group (formerly known as the Nedcor Group) - started its operations in Lesotho under this current company name in 1997 following its previous operations in the country under Standard Bank Limited and Chartered Bank. The bank currently operates branches in Maseru, Leribe, Mafeteng, Mohale's hoek and Butha-Buthe. It offers a full spectrum of personal, business, and corporate banking services ranging from savings accounts, trade finance services, foreign exchange services, as well as offshore investments, and electronic and internet banking services (Nedbank Lesotho, 2017).

First National Bank Lesotho was established in Lesotho in 2004. It has three branches in Maseru as well as branches in Butha-Buthe, Berea, Maputsoe, Leribe and Mafeteng and it has installed ATMs countrywide to support its electronic strategy. Lastly, Lesotho Post Bank (LPB) was incorporated in 2004 as a public company wholly owned by the Government of Lesotho and started its operations in 2005, offering savings and deposit taking services to underbanked and unbanked Basotho population in both rural and urban areas. In 2010, it diversified into lending and introduced electronic transacting services in 2013. To date the Lesotho Post Bank has rolled out 13 branches, a customer service centre and 10 ATMs throughout the country (First National Bank Lesotho, 2017; Lesotho Post Bank, 2017; Commonwealth Network, 2017).

In terms of human resources, the four banks have employed a total of 1,594 employees in different levels of employment. These employees are distributed among the four banks as follows. First, Standard Lesotho Bank has a staff composition of approximately 854 distributed in all its branches throughout the country. Second, Nedbank Lesotho Limited has 
employed a total of a 295 employees distributed across all its operation centres. Third, First National Bank Lesotho has a staff complement of 250 employees also distributed across all its operations around the country. Last, Lesotho Post Bank has employed a total of approximately 195 employees and they are also based in different locations in the country, where the bank has operations (Standard Lesotho Bank, 2017; Nedbank Lesotho, 2017; First National Bank Lesotho, 2017; Lesotho Post Bank, 2017).

\section{Review of the Literature}

\subsection{The Concept of Training}

According to Weil and Woodall (2005) training is regarded as one of the most important functions of Human Resource Management (HRM). It has been defined differently by various authors and human resources management practitioners in the literature. It may be defined as the planned and systematic process of changing behavior through learning events, activities and programs, which assist the participants to acquire knowledge, skills, competencies and abilities to carry-out their work efficiently and effectively (Betcherman, 1992). According to Abiodun (1999) training also changes beliefs, ideas and knowledge, individual's behavioural aspects in their relationships with work groups in the organization. In recent years, many employers around the world have recognized that the success of their organizations heavily depends on the knowledge, skills, competencies and abilities of their workforce. Thus, they allocate resources for continuous investment in training and development to put their organization in a better position to cope with rapid changes in technology and innovation, intensification of competition and organizational change (Beardwell, et al., 2004).

There are many benefits associated with training of employees. Firstly, training enhances employees' development and growth, and creates positive attitudes and behavior. Not only does it boost the company's image in the long run but also enhances employees' efficiency and effectiveness in performing their jobs, which in turn increases company's productivity and ultimately results in financial gain for the company. Secondly, training keeps employees highly motivated. This increases their morale, job satisfaction and reduces labour turnover and absenteeism by cultivating a sense of job security and broadens opportunities for career progression ${ }^{1}$. Thirdly, it boosts companies' competitive edge over their competitors and assists companies to stay ahead of the competition in this continuously changing world, which is characterized by turbulence of change and competitiveness among organizations, market globalization, technological advancement and financial innovation. Fourth, it reduces the costs of production and risks inherent in businesses because trained personnel are not only able to make well-informed investment and financial decisions but also make better economic use of business materials and equipment to avoid wastage in an effort to optimize profits, which consequently increases the value of the firm and shareholders' wealth. Last but not

\footnotetext{
${ }^{1}$ According to Panagoitopoulous and Karamikola (2017) training can have positive indirect influence and also effective on factors like self-confidence, individual and personal basis which are very crucial variables in enhancing job satisfaction.
} 
least, training helps to manage change process by increasing understanding and involvement of employees in the change process and also provides the skills and abilities needed to adjust to new situations as well as prepare employees for future jobs either within or outside an organization (Swanepoel, 2000; Cole, 2002).

In light of these benefits, it is obvious that training goes a long way in assisting organisations to achieve their set goals and survive competition (Peteraf, 1993). However, it should be noted that the benefits of training should not be expected too quickly nor should they be taken for granted. More often, training success is not only dependent on how well and wisely it was designed (internal factors), but also highly relies on external factors such as societal norms and cultural practices. According to Hebert and Doverspike (1990), prior to undertaking any training efforts, managers must ensure that there is a need that can be remedied through such training and there must be a clear training policy guiding that training process. By definition, training process is a systematic approach of developing training programs and it begins with the assessment of training needs, usually at three levels namely; strategic level, tactical level and operational level. At the strategic level, the training needs are determined by the top management by taking into account the overall organizational goals, mission, strategy and problems, which need to be addressed. At the tactical level, the needs are determined by middle management by taking into consideration the development needs to coordinate and allow cooperation between and/or among organizational units. Lastly, at the operational level the needs are determined by lower management and other employees while considering problems emanating from operations such as performance problems associated with individual workers and departments in question.

Buckley and Caple (2009) revealed that training can be initiated in response to two kinds of training needs namely; reactive needs and proactive needs. The former arises out of an immediate and urgent on-job production or productivity shortfall for which a behavioral cause has been identified and separated from other possible causes. By contrast, proactive training need may be associated with organization's corporate strategy and human resource plan. It is future oriented and may come into being for a number of reasons such as anticipated technical developments, the result of management development and personnel replacement action and policies.

The second step in training process involves appropriate design of training programs and consists of setting of training objectives and thinking ahead on how training will be evaluated and transferred at the work place. Training design is followed by delivery of training, which is usually an implementation stage that involves the selection and use of appropriate training methods. There are two broad categories of training methods (techniques) that organizations use to train and develop skills of their employees. These are on- the- job- training and off-the-job-training. On-the-job-training refers to the planned and structured training given to organizational employees while conducting their regular jobs at the workplace and the employees learn by actually performing the job. Examples of on-the job-training techniques include coaching and mentoring, orientation, and job-rotation. On the other hand, off-the-job-training is the form of employees' training that is done away from the employees' actual working environment and can either be long-term or short-term. Examples of 
on-the-job -training techniques include lectures, seminars, vestibule training ${ }^{2}$ and case study (Carrell et.al., 2000; Grobler, et al., 2002).The last step is where training program has to be evaluated and monitored to ensure that it meets the training objectives (Wognum, 2001; Noe, 2008; Grund \& Martin, 2012).

Training can be either specific or general. According to Berker (1962) in Human Capital Theory, general training aims to teach skills and knowledge that can be easily transferred to other institutions or companies, while specific training includes knowledge that is only useful for a limited number of occupations or companies. Notwithstanding the general or specific nature of training, a company's decision to train its employees is largely influenced by the nature of the company or sector it is involved in and the characteristics of the workers it has employed (Zulkifli \& Duasa, 2009). However, companies should not invest in general training due to danger of "poaching" competitors, which could simply offer employees higher paid contracts after a successful general training, and therefore reap the benefits of training without paying for it (Becker,1962). Specific training not only makes it more difficult for competitors to use the knowledge and skills received through employees' training by other organizations but also decreases the likelihood of the employees to change jobs shortly after training.

\subsection{Employees'Performance}

According to Afshan et al. (2012) employees' performance is defined as the attainment of specific tasks by employees of an organization (through the effort applied by employees within such organization) and it is measured against the predetermined or identified standards of accuracy, completeness, cost and speed set by the organization. There are a number of indicators that can be used to measure performance either in the context of organizations or employees, whose performance directly increase that of an organization. On the one hand, a variety of indicators of organizational performance are used including productivity, efficiency, effectiveness, quality and profitability (Ahuja, 2006). According to Wood and Sangster (2002) and Nassazi (2013), profitability refers to the ability of an organization to make profits consistently over a period of time and it is measured as the ratio of gross profit to sales or return on capital employed. Efficiency is the ability to produce the optimal outcomes by employing minimal resources as much as possible while effectiveness is the ability of employees to meet the desired objectives or target (Stoner, 1996). Productivity measures how an individual, organization and industry transforms inputs into output (in the form of goods and services) and it is measured as the ratio output that the firm has produced to the inputs that it has used in producing that output (Stoner et al., 1995; Lipsey, 1989). Lastly, quality is the extent to which the characteristics of products or services produced by an organization

\footnotetext{
${ }^{2}$ In the case of vestibule training, the trainee gets instructions on similar kinds of machine and processes she/he will likely use at the actual workplace. If the employee is going to use a particular machine or computer, she gets training on the same machine or equipment but away from the real work place or floor area. This practice enables the trainee to learn and acquire job skills without necessarily imbibing some bad customs and practices from the actual work environment.
} 
fulfil the requirements and needs of consumers (Kotler \& Armstrong, 2002; Nassazi, 2013). In line with this, organizations always strive to produce products and services that meet certain quality standards to satisfy the consumers.

On the other hand, for an employee some broad performance indicators include quantity, quality, timeliness, cost-effectiveness. Quantity measures the number of units produced, processed or sold against the standard set by the organization while timeliness measures how timely and how fast the work is performed or how fast services are provided. For instance, in the case of a service industry the average customer's downtime is a good indicator of timeliness while the number of units produced per hour is relevant in the case of manufacturing firm. For cost-effectiveness, performance can be measured by the cost of the work performed if the employee has control over costs.

According to Daft (2008), managers are charged with the responsibility of ensuring that organizations strive to achieve high performance levels. In that respect, they set the desired performance targets that their organizations have to achieve periodically, whether annually or quarterly and so on, to meet the predetermined organizational goals and objectives. Since the performance of employees is linked directly to that of the organizations, companies measure the performance of each individual employee against predetermined organizational goals and objectives to ensure that their employees are contributing towards producing high quality products and/or services. This process is called employees' performance management.

\subsection{The Link between Employee Training and the Performance of Employees}

According to Human Resources Management (HRM) literature, the link between training and employees' performanceand that of an organisation is well established. Most of the previous studies in the literature provide evidence of the positive association between these two variables. They show that effective training of employees enhances the performance of such employees not only by making employees competent but also improves their knowledge, skills, abilities and attitudes as well as behaviors necessary for the future job, and this consequently contributes to organizational performance (Wright \& Geroy, 2010; Harrison, 2000; Guest, 1997; Nassazi, 2013). Therefore, the improvement in all these aspects (including competencies) on part of employees enables them to perform their work effectively and efficiently with resultant increase not only in their performance but also in achievement of the firms' objectives in a competitive manner. This places organisations in a better position to face competition and to always stay at the top of their rivals in the market. Furthermore, this greatly reduces job dissatisfaction, complaints, absenteeism and turnover among employees in an organization (Pigors \& Myers, 1989; Nassazi, 2013). Thus, in summary, organisations are encouraged to train their workforce to acquire new skills, knowledge, abilities and attitudes to assist them in performing their jobs efficiently and effectively.

There are many empirical studies that examined the link between training and employees' performance in many developed and developing countries around the world. For instance, Kiweewa and Asiimwe (2014) studied the effect of training on employees' performance at Uganda communication commission (UCC) using data for a sample of 80 out of 108 
respondents drawn through self-administered questionnaires. In order to analyze the data, the study used qualitative method of data analysis in the form of tables and percentiles as well as quantitative technique, especially Pearson correlation analysis. The results showed that training increases the performance of employees at UCC particularly when UCC has handled issues related to needs assessments, training methods and evaluations carefully. Therefore, the study concluded that UCC and other sister organizations in Uganda should always use competent staff or external consultants to formulate strategic plans to guide the implementation and evaluation of organization objectives to enhance achievement of their mandate at all times.

In a related study, Nassazi (2013) examined the effects of training on employee performance at telecommunication industry in Uganda. In particular, this study focused on three biggest telecommunication companies in Uganda namely; Mobile Telephone Network (MTN), Warid and Uganda TeleCom (UTL). In this study, the data was collected through the structured questionnaire, which was distributed to 120 respondents at these three companies and was analysed through descriptive statistics techniques especially the frequency and percentage distributions. The analysis of the results revealed that training has a positive impact on the performance of employees of these companies in Uganda. Therefore, the study concluded that these findings would be helpful to human resources policy decision makers, government and academic institutions in Uganda.

Khan (2012) used a sample of 100 employees from Habib Bank and Federal Urdu University of Arts Science and Technology Islamabad in Pakistan to study the effects of training and motivation on employees' performance. The study used a structured questionnaire for data collection and analyzed such data using Pearson correlation and regression analysis. The results of the study showed that both training and motivation positively affect the performance of employees. Therefore, the conclusion was that apart from technology, management behavior and working environment, having good training plans for employees enhances the performance of employees in an organization.

In another empirical study conducted in Karachi, Pakistan, Hafeez and Akbar (2015) examined the impact of training on employee performance in the four companies. For this purpose, a sample of 356 employees was selected through random sampling technique and data collection was done by means of a self-administered questionnaire. The data analysis through Statistical Package for Social Scientists (SPSS) 19 version revealed a statistically significant and positive relationship between training and employees' performance at these four companies. Therefore, it was concluded that the training of employees not only improves efficiency and effectiveness of employees in performing their jobs but it also enhances the efficiency of the companies in which they work.

In an effort to fully exploit the issue in Pakistan, Ahmad et al. (2014) also studied the impact of employees training and development on employees' performance in the banking sectors in North Punjab, Pakistan. The paper used a structured questionnaire to collect data from a sample of 100 employees of 11 banks in the districts of Multan and Bahawalpur Punjab Province and employed regression analysis based on SPSS 20 version for data analysis. The 
results showed a significant positive relationship between training and development and the performance of employees. In addition, the empirical findings supported a positive relationship between on-job- training and employees' performance and a positive relationship between mode of training delivery and employees' performance in the banking sector in Pakistan.

As if that was not enough, Sultana et al. (2012) examined the impact of training on employees' performance in the telecommunication sector in Pakistan. Analysis of the data collected from five telecom companies through 360 questionnaires showed that training has a strong positive effect on employees' performance in these companies. Furthermore, the study observed that most organizations in Pakistan meet their training needs in an ad hoc and haphazard manner while others start by identifying their training needs, then design training activities in a rational manner based on training needs analysis and finally assess results of the training in line with human resources management practices in recent years. Therefore, the study recommended that organizations should invest in the right type of employee training in order to enhance employees' performance and produce highly competent and skilled workforce for the betterment of the organization. In addition, this study concluded that training is a useful tool that enables employees to cope with changes in technology, market competition, organizational restructuring.

Inaddition, Stavrinoudis and Psimoulis (2015) examined the impact of employees' education on HRM performance in five, four and three star hotels in Attica, Athens. In order to undertake this study, the authors used a structured questionnaire, which was completed by HR managers of these hotels during the period; January - February 2015. The results from regression analysis showed that effective and integrated HR education and training policies improve the performance of employees at these hotels. Dabale et al. (2014) also used a sample of 132 respondents, comprising of 91 males and 41 females, selected through purposive sampling technique and structured questionnaire to examine the relationship between training and employees' performance in Mature City Council, Zimbabwe. For this purpose, employed quantitative techniques including inferential statistics in an attempt to describe and measure the degree of association between these two variables. The results revealed a strong positive relationship between training and performance of the employees at Mature City Council. Specifically, the study found that training enhances employees' knowledge, skills, abilities and competencies. In addition, it was observed that training also alters the behaviour of employees and assists in terms of achievement of organisational goals as well as reconciles the gap between what should happen and what is actually happening on the ground. Therefore, the study recommended that all stakeholders, the mayor, directors, senior managers, junior managers, supervisors and the employees in the Mature City Council and other organizations in Zimbabwe should be involved in one way or the other in training in order to enhance their knowledge, skills, ability, competencies and behaviour.

\subsection{Training and the Employees' Motivation}

Motivation has been defined differently by various authors in the literature. Nonetheless, all of these definitions have some words in common such as desire, want, wishes, aim, goals, 
needs, and incentives (see Khoshnevisa \& Tahmasebib, 2016). For instance, Shahzadi et al. (2014) defined motivation as a force that enables an individual to act in the direction of a particular objective. On the other hand, Zlatea and Cucui (2015) defined it as the availability of an individual to work intensely and consistently in an effort to achieve set organizational objectives, with the hope that the effort made will lead to the realization of some individual objectives generated by the needs that the individual feels. According to Zlatea and Cucui (2015), these individual objectives are veritable reasons determining the employees to act and work in organizations. According to Grant (2008) motivation influences productivity, performance and persistence at workplace. Motivated employees are more oriented towards autonomy and freedom and are more self-driven as compared to less motivated employees (Ryan \& Deci, 2000 ;Thomas, 2002). In addition, they are more committed to their work compared to less motivated employees (Guay et al., 2000; Vansteenkiste et al., 2006). Other studies in the literature, which support the positive link between employee training and motivation include Omollo (2015), Subari \& Riady (2015) and Nabi et al.(2017).

\subsection{Training and the Job Satisfaction}

The concept of job satisfaction has also been defined differently by different HRM practitioners in the literature. It is generally defined as the feeling, thoughts and a general attitude of the employees towards their jobs and place of work as well as the job components such as the working environment, working conditions, equitable rewards and communication with the colleagues (see Togia et al., 2004; Kim et al., 2005; Armstrong, 2006). According to Skaalvik and Skaalvik (2011), job satisfaction actually occurs when the employees' expectations from the job matches with the real outcome. On the other hand, Kinicki and Kreitner (2007) states that other scholars in the literature measured job satisfaction in terms of need fulfilment, discrepancies, value attainment, equity and dispositional or genetic components models. Following Ocen et al. (2017), this paper measured job satisfaction in terms of extrinsic and intrinsic job-related factors. On the one hand, extrinsic factors include all the external factors, which may satisfy employees such as communication style, supervisor co-operation, pay and working conditions. On the other hand, intrinsic factors may comprise of things like the type of work the workers perform and the duties considered by the employees in an organization.

There exists a link between employee training and job satisfaction. According to Sajuyigbe and Amusat (2012) employee training actually improves the employees' satisfaction about their jobs. In fact, Siebern (2005) and Owens (2006) found that training and job satisfaction are positively correlated and that those employees who are offered some kind of training by their organizations are more gratified than those who do not receive such training. These results were also supported by Adesola et al. (2013) who established that staff training has a positive impact on job satisfaction among banks' employees in Nigeria. These views were also corroborated by Chen et al. (2004) who argued that training reduces employees' anxiety or frustration brought about by work demands, with which they may not be familiar or aware of. Furthermore, Rowden and Conine (2005) argued that thoroughly trained employees are satisfied with their jobs; this in turn makes them satisfy the needs of their customers. 


\section{Mll Macrothink}

International Journal of Human Resource Studies

ISSN 2162-3058

2018, Vol. 8, No. 2

Consequently, such employees become committed to their organizations, attend work, stay with an organization, arrive at work on time, perform well and engage in behaviors that are helpful to the organization (see Aamodt, 2007; Wright \& Bonett, 2007; Eleswed \& Mohammed, 2013, among others).

\subsection{Conceptual Framework}

Conceptual framework refers to a diagrammatical representation that depicts the relationship between a dependent variable and independent variable (Young, 2009). In the current research, conceptual framework presents the relationship between training and employee performance, employee motivation and job-satisfaction in Lesotho. More specifically it portrays that training of employees affects employees' performance, employees' motivation and job satisfaction in Lesotho.

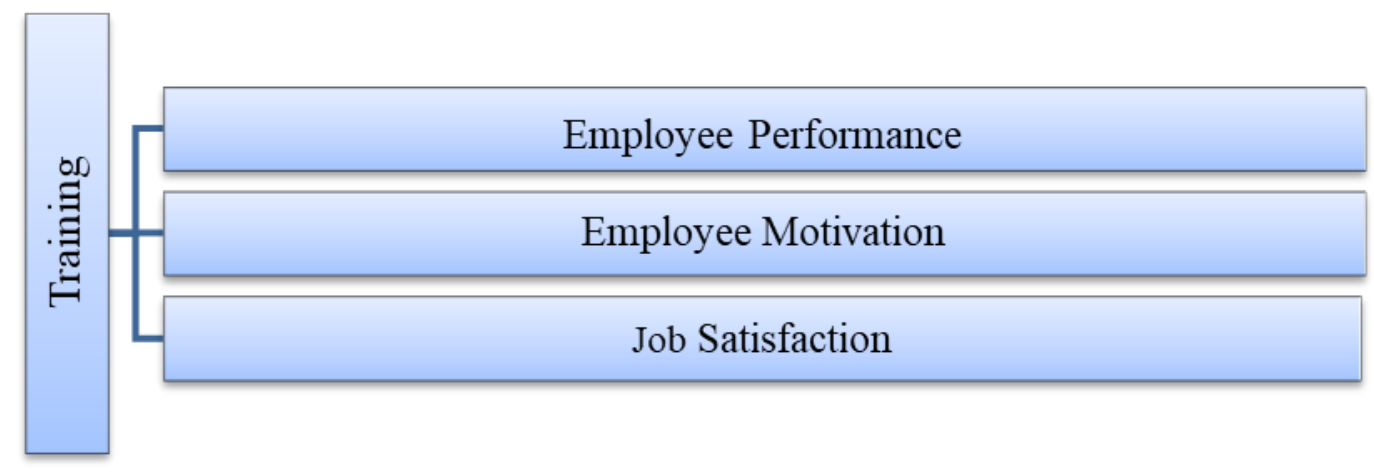

Figure 1. Conceptual framework

\section{Research Methodology}

\subsection{Design of the study}

According to the literature, research designs consist of the methods that are used for the collection, measurement and analysis of the data in line with the research objectives. There are different research designs that researchers can adopt to collect, measure and analyze the data related to study. These include qualitative research designs, quantitative research designs or a mixture of both. However, this study utilized qualitative research design in the form of survey method. This method was suitable for this study as the researchers did not have any control over the variables and the outcomes. In addition, it provided an insight about the phenomena in question and it was flexible in the sense that it helped in identifying the missing part of what is unknown or partially known (Ghauri \& Grönhaug, 2005).

\subsection{Data Sources and Collection Methods}

This study used primary data collected through self-administered questionnaire consisting of open-ended questions and closed questions some of which are anchored on a 5-Likert scale for measurement of various constructs. This allowed the respondents to answer the questions at their own spare time and contributed towards improving the accuracy of the responses given by the respondents. 


\subsection{Target Population, Sample Size and Sampling Technique}

By definition, population is a group of people or objects from which a sample is to be chosen. In the context of the current study, the exact target population was supposed to consist of a total of 1594 employees of the four commercial banks (854 employees from Standard Lesotho Bank, 250 employees from First National Bank Lesotho, 295 employees from Nedbank Lesotho and 195 employees from Lesotho Post Bank) from all the branches throughout the country. However, since it would be cumbersome to study this large population due to a number of reasons including, but not limited to, time constraint, costs and accessibility, the target population for the study was reduced to a total of 300 employees consisting of 40 top management employees, 100 middle management employees and 160 junior level employees from the commercial banks branches (including headquarters based in Maseru district) in Lesotho. Based on these categories, a representative sample consisting of all the categories of employees was chosen for the study through stratified sampling to ensure that all these categories of employees were represented in the sample. The sample for the study was determined by using the following formula:

$$
n=\frac{N}{1+N(e)^{2}}=\frac{300}{1+300(0.05)^{2}}=171
$$

Where $n$ is the optimum sample size, $N=300$ is the target population of all the employee of the four commercial banks while $e$ is the probability of error determined as the 0.05 for $95 \%$ confidence level. Using proportionate sampling, this sample was finally split into 23 top management employees, 57 middle level employees and 91 junior employees to make a total of 171 employees chosen from the commercial banks in Lesotho.

\subsection{Validity of the Research Instrument}

Validity refers to the extent to which a research instrument measures what it is intended to measure (Kothari, 2004; Uyimadu, 2005). The validity of the instrument, which is a questionnaire in this case, that was used for data collection was determined by ensuring that all the questions contained in the questionnaire were in line with the study's overall research questions as well as its objectives. The questionnaire was validated through pilot testing by some respondents to test their understanding and interpretation of the questions to ensure that such questions bear some meaning and the comments and/or queries raised by those respondents were used to fine-tune the questionnaires.

\subsection{Reliability of the Research Instrument}

Reliability is defined as the extent to which the research instrument that is used for data collection in the study demonstrates consistency with the objectives (Gay, 1996). In order to ensure reliability of the instrument, the questionnaire was verified by ten HRM specialists with better understanding of scientific research methods. For purposes of clarity, the questionnaire was further piloted tested and consequently fine-tuned. 


\subsection{Method of Data Analysis}

The data obtained through questionnaires was analyzed by using descriptive statistical techniques mainly frequency distribution tables and pie charts. These tools showed the percentage or proportion of respondents who choose a certain response over others.

\section{Data Analysis and Interpretation of the Results}

\subsection{Analysis of the Response Rate}

As indicated earlier, a sample of 171 employees was selected from a total of 300 employees from the four commercial banks in Lesotho. In this regard, a total of 171 questionnaires were issued and distributed to the employees to gather the necessary data for the study. The respondents were given a maximum of two months to fill the questionnaires with an aim to achieve high questionnaire response rate. Table 1 presents the number of questionnaires that were issued and distributed to the respondents and those that were finally returned by the respondents. As indicated in Table 1, only 95 questionnaires (representing 56 percent of all issued questionnaires) were successfully filled and returned by the respondents. This response rate was considered to be good and representative of all employees of the four commercial banks because it accounted for more than 50 percent of the sample and at least the response rate was more than 50 per cent per commercial bank. Therefore, the information collected through the questionnaires was used to derive generalizations and draw conclusions for the study.

Table 1. Questionnaire response rate

\begin{tabular}{l|c|c|c}
\hline \multicolumn{1}{c|}{ Name of the Bank } & $\begin{array}{c}\text { Number of } \\
\text { Questionnaires } \\
\text { distributed }\end{array}$ & $\begin{array}{c}\text { Number of } \\
\text { Questionnaires Received }\end{array}$ & $\begin{array}{c}\text { Response rate } \\
\text { (in percentage) }\end{array}$ \\
\hline Standard Lesotho Bank & 91 & 51 & $56 \%$ \\
First National Bank & 27 & 15 & $56 \%$ \\
Nedbank Lesotho Limited & 32 & 17 & $53 \%$ \\
Lesotho Post Bank & 21 & 12 & $57 \%$ \\
\hline Total & $\mathbf{1 7 1}$ & $\mathbf{9 5}$ & $\mathbf{5 6 \%}$ \\
\hline
\end{tabular}

Source: Researchers' own Computations from the questionnaire

\subsection{Biographical Characteristics of the Respondents}

With a presumption that the respondents' age, gender and employment levels (or positions) at the commercial banks could influence their opinions regarding the effect of training on employees' performance as well as the effects of training on motivation and job-satisfaction, the study first analyzed demographic (biographical) information of the respondents. Table 2 provides biographical information about the respondents to determine their age and gender distribution and the ranks (positions) they hold at the commercial banks as well as their years of experience within the banks. This information is important as it indicates whether or not there was a significant difference in opinion regarding the effect of training on employees' performance, job satisfaction and employees' motivation based on respondents' age, gender, and years of experience. Table 2 shows the frequency and percentage distributions of the age and years of experience of the respondents while Table 3 displays the frequency and 
percentage distributions of the gender and ranks of the respondents. The results show that 32 percent of the respondents who participated in the study were in the age group of 18-25 years, 52 percent were in the age group of 26-35 years while only 16 percent were in the age group of 36-45 years. In terms of years of experience, the results show that approximately 39 percent of the respondents had 4-7 years of work experience, about 32 percent of the respondents had 3-5 years of work experience and approximately 16 percent had 0-2 years of work experience at the commercial banks.

Table 2. The Distributions of the respondents' age and years of experience

\begin{tabular}{l|c|c|c|c|c}
\hline \multicolumn{3}{c|}{ Age of the Respondents } & \multicolumn{3}{c}{ Years of Experience (Number of years of } \\
employment)
\end{tabular}

Source: Researchers' own Computations from the questionnaire

Table 3. Respondents' gender and employment ranks

\begin{tabular}{c|c|c|c|c|c}
\hline \multicolumn{2}{c|}{ Gender of the Respondents } & \multicolumn{2}{c}{ Level of Employment (Ranks) } \\
\hline Gender & Frequency & Percentage & Rank & Frequency & Percentage \\
\hline Male & 53 & 56 & Top Management & 19 & 20 \\
Female & 42 & 44 & Middle Management & 33 & 35 \\
& & & Lower level & 43 & 45 \\
\hline Total & $\mathbf{9 5}$ & $\mathbf{1 0 0}$ & Total & $\mathbf{9 5}$ & $\mathbf{1 0 0}$ \\
\hline
\end{tabular}

Source: Researchers' own Computations from the questionnaire

Regarding gender, the majority of the respondents in the survey were males. Specifically, 56 percent of the respondents were males while females only constituted 44 percent of the respondents. Thus, there was a small gender gap in the study as far as the sample was concerned. This finding indicates that the study received higher response rate in males than in females in banking sector in Lesotho. With regard to the ranks of employment, it was established that the majority of the respondents who participated in the study were junior employees. In particular, 45 percent of the respondents in the study occupied junior positions, 35 percent occupied middle management positions while only 20 percent occupied top management roles within the commercial banks.

Apart from the demographic information, important information relating to the respondents in the study that was worth of the analysis was their level of education and the areas of work (departments) within which they work in the commercial banks. Table 4 presents the respondents' areas of work within the commercial banks and their level of education. The analysis showed that the respondents were working in a diverse of areas within the banks. In addition, their level of education also varies widely according to the four qualifications, namely; certificates, diplomas, bachelors' degrees, and masters. Specifically, 10 percent of 
the respondents held certificate qualifications, 32 percent of them held bachelors' degree, 25 percent held diploma while 28 percent held masters' degree.

Table 4. Respondents' Areas of work within banks and their level of education

\begin{tabular}{|c|c|c|c|c|c|}
\hline \multicolumn{3}{|c|}{ Area of Work } & \multicolumn{3}{|c|}{ Level of Education } \\
\hline Departments & $\begin{array}{c}\text { Number of } \\
\text { respondents }\end{array}$ & Percentage & Qualification & $\begin{array}{c}\text { Number o } \\
\text { Responder } \\
\text { S }\end{array}$ & rcentag \\
\hline Operations & 12 & 12.6 & Certificate & 10 & 11 \\
\hline $\begin{array}{c}\text { Corporate and investment } \\
\text { banking }\end{array}$ & 4 & 4.2 & Diploma & 25 & 26 \\
\hline Finance & 5 & 5.3 & Bachelor Degree & 32 & 34 \\
\hline Digital banking & 10 & 10.5 & Masters & 28 & 29 \\
\hline Retail banking & 7 & 7.4 & & & \\
\hline Express banking & 5 & 5.3 & & & \\
\hline Fraud management & 6 & 6.4 & & & \\
\hline Business support unit & 9 & 9.5 & & & \\
\hline Compliance & 2 & 2.1 & & & \\
\hline Customer contact centre & 14 & 14.7 & & & \\
\hline Business support unit & 11 & 11.6 & & & \\
\hline Human Resources & 6 & 6.4 & & & \\
\hline Business banking & 4 & 4.2 & & & \\
\hline Total & 95 & 100 & Total & 95 & 100 \\
\hline
\end{tabular}

Source: Researchers' own Computations from the questionnaire

In summary, the distribution of the respondents according to these six characteristics indicated that the respondents who took part in the study were from a diverse background and hence all demographic information pertaining to them was considered. In light of this, it was concluded that the sample of employees used in the study was considered to be representative of all commercial banks' employees and therefore the conclusions that would be derived from the analysis of this sample would be similar to those that would have been drawn from the entire population of employees in the banking sector in Lesotho.

\subsection{Participation of Employees in Training, Employees' Selection for Training and the} Frequency of Training

Following the analysis of the respondents' demographic information, the study dwelled on issues regarding the employees' training and how employees were selected for training by the commercial banks. The results in the Table 5 showed that a total of 83 respondents, who accounted for approximately 87 percent of all those who participated in the study, attended training related to their jobs at the commercial banks for which they work. The remaining 12 respondents, representing about 13 percent of all the respondents, indicated that they had not gone through any sort of training related to their jobs at their workplaces. 


\section{Macrothink}

International Journal of Human Resource Studies ISSN 2162-3058 2018, Vol. 8, No. 2

Table 5. Respondents' participation for training and criteria used for their selection for training

\begin{tabular}{c|c|c|l|c|c}
\hline $\begin{array}{l}\text { Respondents' Participation in } \\
\text { Training }\end{array}$ & \multicolumn{3}{l}{ Criteria used for Respondents' Selection for Training } \\
\hline Response & $\begin{array}{c}\text { Frequenc } \\
\text { y }\end{array}$ & $\begin{array}{c}\text { Percentag } \\
\text { e }\end{array}$ & \multicolumn{1}{|c}{ Criteria } & Frequency & Percentage \\
\hline Yes & 83 & 87.4 & On joining the company & 24 & 25.3 \\
No & 12 & 12.6 & Supervisors recommendation & 18 & 18.9 \\
& & & Compulsory for all employees & 39 & 41.1 \\
& & & Upon employee request & 14 & 14.7 \\
& & & Performance Appraisal & 0 & 0 \\
\hline Total & $\mathbf{9 5}$ & $\mathbf{1 0 0}$ & Total & $\mathbf{9 5}$ & $\mathbf{1 0 0}$ \\
\hline
\end{tabular}

Source: Researchers' own Computations from the questionnaire

Table 5 also illustrates the criteria that the commercial banks in Lesotho used to select employees for training. The results indicated that none of the respondents who attended training were selected for such training based on performance appraisal results. However, all of them were selected based on criteria such as supervisors' recommendation, request made by themselves, compulsory request made by the company either when they initially joined the commercial banks or during the course of their employment at the banks. Specifically, the results revealed that the majority of the respondents, representing 41 percent of the respondents, received training because it was compulsory for all employees during the course of employment at the commercial banks while about 25 percent of them received it immediately when they joined the banks. In addition, approximately 19 percent of the respondents were selected based on their supervisors' recommendation while about 15 percent of them received it as a result of their own requests.

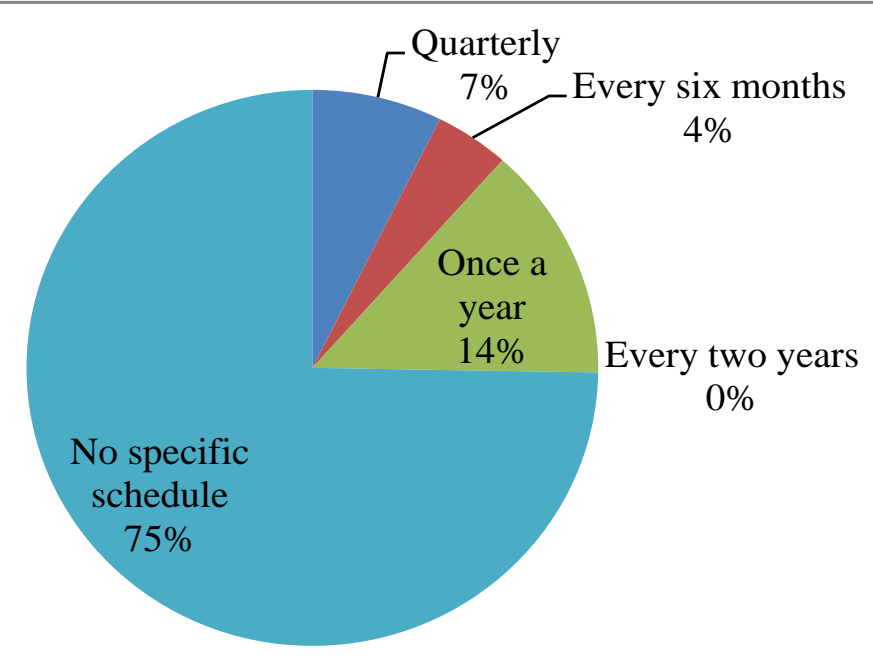

Figure 2. Frequency of employees training

Source: Researchers' own Computations from the questionnaire

As a follow-up to the issue of participation in training, the respondents were also asked how often the commercial banks offer them training in a year. Figure 2 illustrates the frequency at which the commercial banks offered training to employees at their workplaces. The analysis 
of the findings revealed that approximately 75 percent of the respondents, representing the majority of the respondents, indicated that the training they received at their workplaces does not actually follow any specific schedule. In addition, 14 percent of the respondents said that they attend training once in a year, 4 percent of the respondents said that the commercial banks offer them training every six months while about 7 percent of them said they received it quarterly. These findings could imply a number of things including the fact the commercial banks in Lesotho do not have clear training policies for their employees. This may necessitate development of such training policies in order to guide management and employees about all issues related to training of staff within the commercial banks.

\subsection{The Methods Used for Training Facilitation}

In addition, the respondents were also asked about the methods of training that were used by the commercial banks during the training and their impact on their understanding of the training materials. Figure 3 depicts the methods of training which were used for employees training. The results reveal that variety of training methods was employed to offer training to the employees. These include presentations, discussions, seminars and lectures. With respect to their usage, the majority of the respondents indicated that presentations were the most commonly used training facilitation methods by the commercial banks, followed by demonstrations, lectures, discussions and seminars. In particular, 51 percent of the respondents said that their training was facilitated through presentations, 18 percent of them mentioned that it was done through demonstrations while 12 percent of the respondents said theirs was done through lectures. In addition, 10 percent of the employees who participated in the study mentioned that discussions were used to facilitate the training while 9 percent of them said that their training was conducted through seminars. These results indicate that the commercial banks strongly use presentations and demonstrations to training their employees partly due to the customer-oriented nature of the business they do.

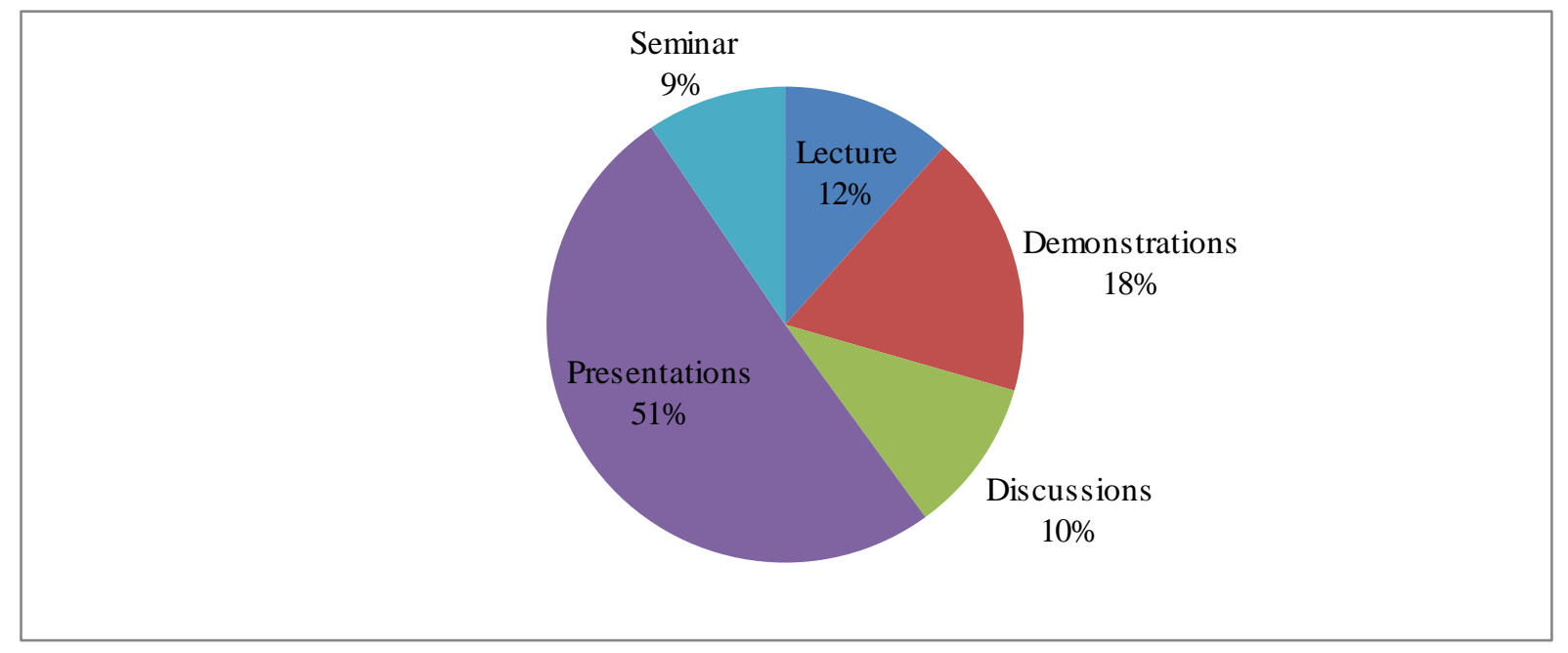

Figure 3. The methods of training facilitations used by the commercial banks in Lesotho Source: Researchers' own Computations from the questionnaire 


\subsection{The Impact of Training on the Performance of Employees}

Table 6 below summarizes the views of the respondents regarding the effect of training on their performance at the banking sector. The results clearly indicate that about 61 percent of 95 sampled respondents linked training to improved performance because it sharpens their knowledge, skills, capabilities and competencies at the workplace. These ultimately assist them to cope with the dynamic working environment in the advent of rapid technological advancement, globalization and financial liberalization, all of which have led to huge changes in the financial sector worldwide through significant developments in the money and capital markets. On other hand, the remaining 37 respondents, constituting 39 percent of the respondents who participated in the study, declared that the training they received at their workplace did not enhance their work performance. In this regard, the majority of the respondents alluded to the fact that training positively influences employees' performance and this finding is very important because it is the centre of this study. This result is in line with other studies in the literature which indicate that training positively impacts on employee performance by improving employee skills, capabilities and competencies, which enable them to know and perform their jobs better (see Wright \& Geroy, 2010; Swart, et al., 2005; Harrison 2000; Nassazi,2013).

Table 6. The effect of training on employees' performance

\begin{tabular}{l|l|l}
\hline Response & Frequency & Percentage \\
\hline Yes & 58 & 61 \\
No & 37 & 39 \\
\hline Total & $\mathbf{9 5}$ & $\mathbf{1 0 0}$ \\
\hline
\end{tabular}

Source: Researchers' Computations from the questionnaires

\subsection{The Impact of Training on Employee's Motivation}

The study also explored the extent to which training motivates employees in the banking sector in Lesotho. Figure 4 below presents the responses of the sampled employees to the questions regarding the effect of training on motivation of employees. The results revealed that indeed training motivates employees; with approximately 96 percent of the respondents arguing that training had a positive impact on their motivation. Specifically, approximately 42 percent of the respondents in the study argued that training had very high impact on their motivation at the commercial banks where they work while about 31 percent and 18 percent of the respondents, respectively, alluded that training had a high impact and moderate impact on their motivation at workplaces. Furthermore, about 5 percent of the commercial banks' employees who responded to the questionnaire argued that the training of employees had a slight impact on their motivation. However, only 4 per cent of the respondents in the study stated that training does not have any impact, whatsoever, on their motivation at their workplace. Therefore, in summary the study generally established that training indeed enhances employee motivation. This finding is consistent with the empirical findings of most studies in the literature. These studies include Sahinidis and Bouns (2008), Omollo (2015), Subari and Riady (2015), Nabi et al. (2017) who found that training practices used by organizations have a direct or indirect positive impact on employees' motivation. 
Table 7. The effect of training on motivation of employees

\begin{tabular}{l|l|l}
\hline Response & Frequency & Percentage \\
\hline No positive impact & 4 & 4.2 \\
Slight positive impact & 5 & 5.3 \\
Moderate positive impact & 17 & 17.9 \\
High positive impact & 29 & 30.5 \\
Very high impact & 40 & 42.1 \\
\hline Total & $\mathbf{9 5}$ & $\mathbf{1 0 0 . 0}$ \\
\hline
\end{tabular}

Source: Researchers' own Computations from the questionnaire

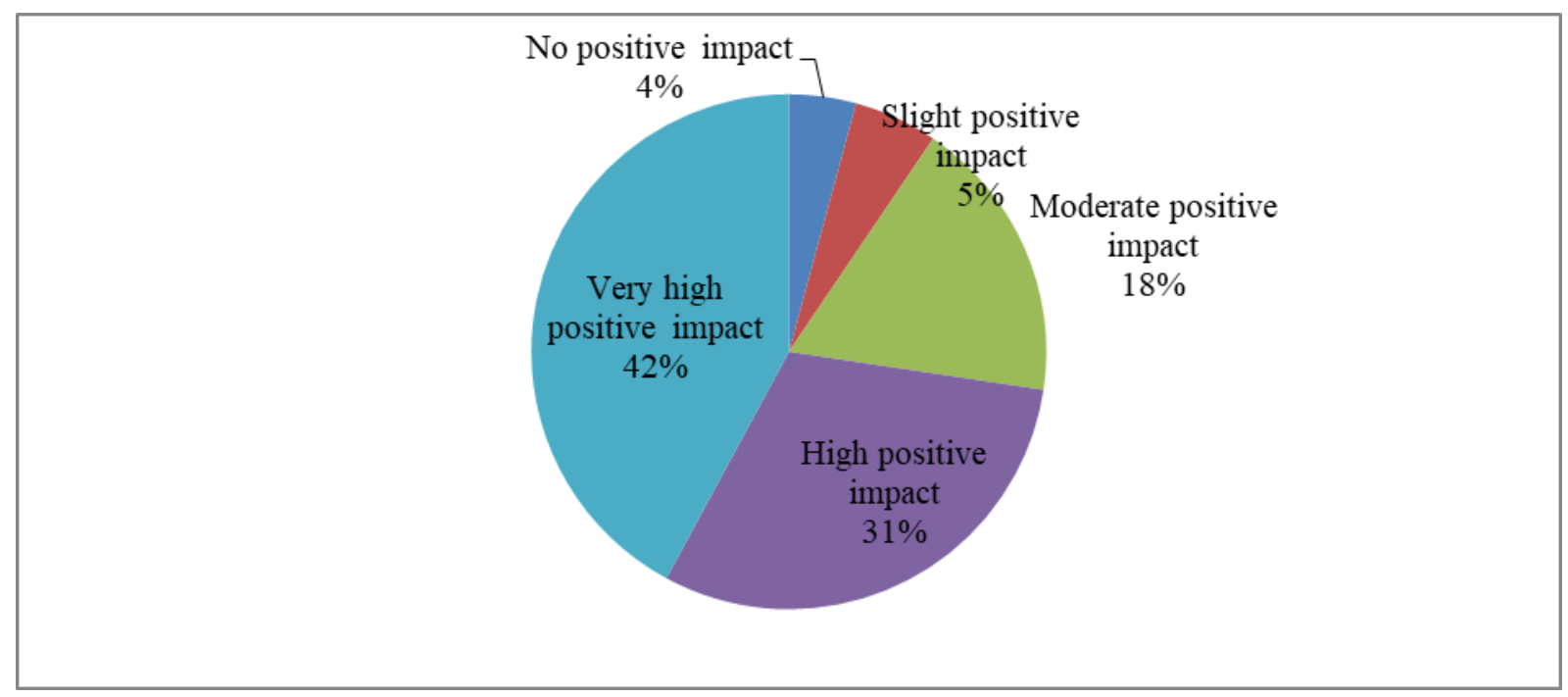

Figure 4. The effect of training on motivation of employees

Source: Researchers' own Computations from the questionnaire

\subsection{The Impact of Training on Job Satisfaction}

As part of its objectives, the study further also explored the extent to which training affected job-satisfaction of employees in the banking sector in Lesotho. Figure 5 indicates the responses of the sampled employees regarding the effect of training on job-satisfaction. Figure 5 provides evidence that 91 percent of the respondents argued that training impact positively on their job-satisfaction at their workplace. In particular, approximately 37 percent of the respondents indicated that training very highly and positively affected their job satisfaction at the commercial banks while 18 percent of them indicated that training highly increased their employee motivation at the workplace. In addition, about 22 percent and 14 percent of the respondents, respectively, argued that training moderately and slightly increased their job-satisfaction at workplace. Nonetheless, only 9 percent of the sampled respondents who participated in the study argued that training did not have a positive impact on job satisfaction. Thus, there is sufficient evidence to conclude that training has a positive effect on employees' job satisfaction in the banking sector in Lesotho. These results are consistent with the results obtained by Burgard and Goerlitz (2011), Aarti et al. (2013), Ljigu (2015) and Ocen et al. (2017) who established that training positively influences job-satisfaction by enhancing staff relationship at work. They argued that high 
job-satisfaction is more likely to increase employees' commitment to their organizations, reduce absenteeism, job-turnover and increases employees' loyalty to the organisation. Therefore, the commercial banks in Lesotho and other institutions should always set aside some training budgets for their employees to boost their job satisfaction as this ultimately have positive spillover effects on the organisation performance as a whole.

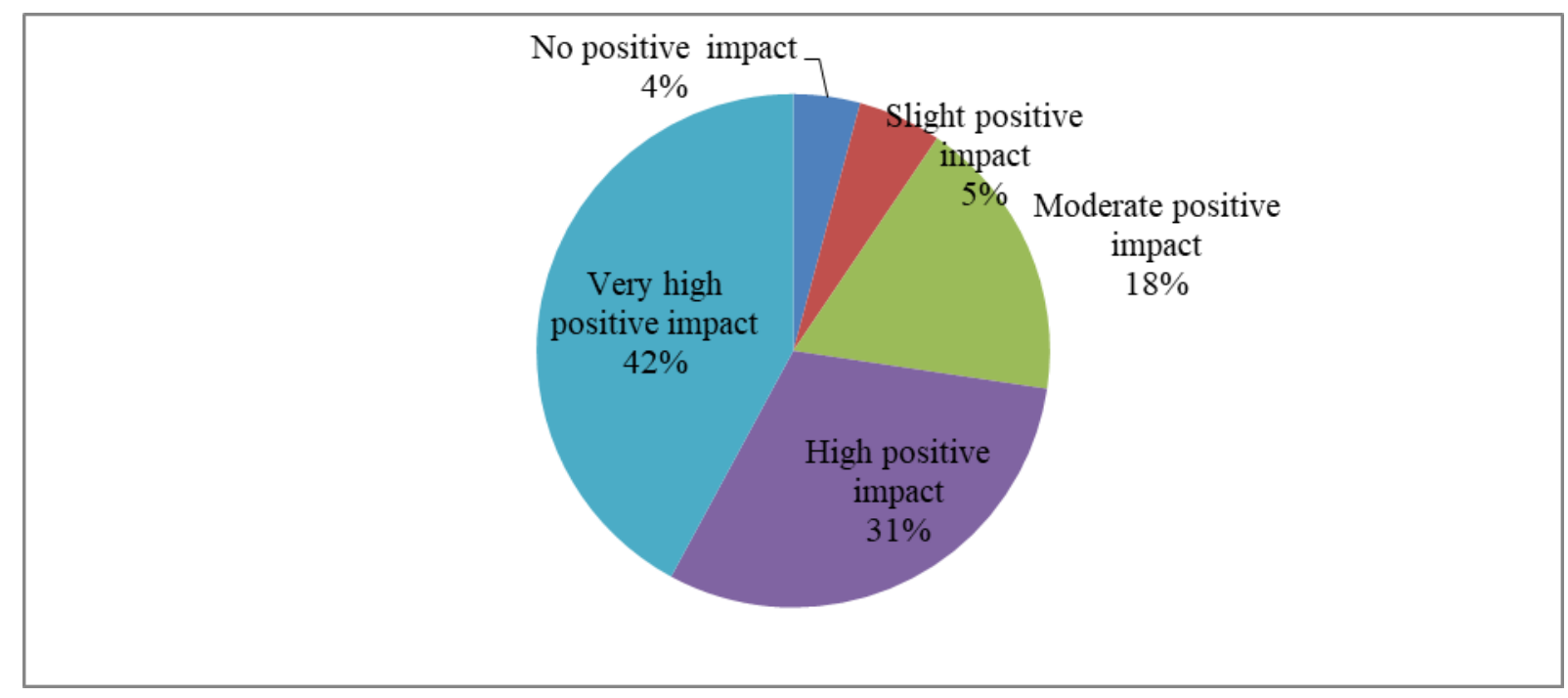

Figure 5. The impact of training on job satisfaction

Source: Researcher's own Computations from the questionnaire

\section{Conclusion and Recommendations}

The importance of training in the corporate world has been widely discussed in the HRM literature and there is a large body of the theoretical and empirical literature, which provides empirical evidence in support of either direct or indirect link between training and employees' performance, motivation and job satisfaction with resultant positive spillovers on organizational performance. This is because the success and failure of any organisation to achieve its objectives depends highly on training of its workforce. Therefore, top management within organisations should realize the importance of investing in employees' training for the sake of improving their performance and hence that of an organisation. Nevertheless, some organizations (including the commercial banks) in Lesotho seem not to recognize this importance because they continue to squeeze training budgets when their financial positions are not good and this situation incapacitates employees, lowers performance, demotivates them, increases job turnover and the costs of hiring new employees, which consequently reduces the organizational profitability. Thus, this paper examined the impact of training on employees' performance, employees' motivation and job satisfaction in the context of the banking sector in Lesotho not only with a view to fill existing research gap in this area in Lesotho but also to convince policymakers and managers in various organizations (including commercial banks) about the value of training on employee's performance (productivity), employees' motivation and job-satisfaction. In addition, the study also contributes to the general body of knowledge in the literature on the link among these variables in developing countries. 


\section{$\triangle$ Macrothink}

The study employed stratified sampling technique to draw a sample of 171 employees from a population of 300 employees in the banking sector in Lesotho through self-administered questionnaire and used descriptive statistical techniques for data analysis. The results of the study revealed that the majority, 61 percent, of the respondents linked training to improved employees' performance in the banking sector in Lesotho while only 39 percent of the respondents argued that training had no positive impact on the employees' performance in the banking sector in Lesotho. In addition, the findings further showed that approximately 96 percent of the respondents argued that training positively affected employees' motivation. Besides this, the majority, 91 percent, of the respondents also indicated that training also increased job satisfaction of the employees at the commercial banks in Lesotho. These empirical findings are not only also consistent with the results of other similar studies in the literature but also have important policy implications for managers and policy makers in the banking sector and, probably, in other organisations in Lesotho regarding issues related to improving employees' performance and/or general organizational performance. First, the banking sector in Lesotho should always set aside budgets solely dedicated for employees' training based on identified skill gaps to sharpen employees' skills, capabilities, knowledge and competencies to capacitate them to cope with the dynamic working environment in the advent of significant financial innovation and financial development and liberalisation. Second, the banking sector should develop training policies and ongoing training programmes with a view to enhance employee performance, motivation and job-satisfaction. Not only will these increase employees' loyalty and commitment towards their organisations but will also ultimately assist organisations to achieve strategic objectives, vision and mission. Last but not least, the banking sector should also regularly review and improve employees' working conditions and remuneration packages and benefits in order to retain their talented workforce as such employees always become attractive to other organizations, which often want to build strong human resources to enhance their competitive edge against their rivals.

\section{Acknowledgement}

The authors wish to express their deepest appreciation to the anonymous reviewers and the editor of the International Journal of Human Resources Studies for their useful comments and publication of this paper.

\section{References}

Aamodt, M. G. (2007). Industrial/Organisational Psychology: an applied approach, Wadsworth Cengage Learning, Belmont, CA.

Aarti, C., Seema, C., Bhawna, C., \& Jyoti, C. (2013). Job satisfaction among bank employees: an analysis of the contributing variables towards job satisfaction. International Journal of Scientific Technology Research, 2(8), 11-22.

Abiodun, E. J. A (1999). Human resources management: an overview: Concept Publication, Shomolu, Lagos.

Adesola, M. A., Oyeniyi, K. O., \& Adeyemi, M. A. (2013). Empirical study of the relationship between staff training and job satisfaction among Nigerian banks employees. 
International Journal of Academic Research in Economics and Management Sciences, 2(6), $108-115$.

Adnan, K., \& Bataineh, A. (2014). Impacts of training on employee performance of commercial banks in Jordan, European Journal of Business and Management, 6(27), 192 $-196$.

Adongo, A. J. Examining the effects of job training on employee performance in mobile telephone industry. A case of telkom orange Nakuru, Kenya (Doctoral dissertation), Kenyatta University.

Afsana, J., Afrin, F., \& Tarannum, T. (2016). Effect of training on employee performance: an empirical study on telecommunication industry in Bangladesh. Journal of Business and Technology (Dhaka), 10(2), 67-80. https://doi.org/10.3329/jbt.v10i2.29468

Afshan, S., Sobia, L., Kamran, A., \& Nasir, M. (2012). Impact of training on employee performance: a study of telecommunication sector in Pakistan. Interdisciplinary Journal of Contemporary Research in Business, 4(6), 646-661.

Ahuja, K. (2006). Personnel management, $3^{\text {rd }}$ ed., New Delhi: Kalyani Publishers.

Armstrong, M. (2002). A Handbook on personnel management practice, $5^{\text {th }}$ ed., London: Kogan Publishers.

Armstrong, M. (2006). A Handbook of human resource management practice, 10th ed., Kogan Page Publishing, London,

Athar, R., \& Shah, F. (2015). Impact of training on employee performance (banking sector Karachi). IOSR Journal of Business and Management, 17(11), 58-67.

Awang, A. H., Ismail, R., \& Mohd Noor, Z. (2010). Training impact on employee's job performance: a self-evaluation. Economic research-Ekonomska istraživanja, 23(4), 78-90. https://doi.org/10.1080/1331677X.2010.11517434

Bataineh, K. (2014). Impacts of employee training on the performance of commercial banks in Jordan. European Journal of Business and Management, 6(27), 192-196.

Beardwell, L., Holden, L., \& Claydon, T. (2004). Human resource management: a contemporary appeal. $4^{\text {th }}$ ed., Harlow: Prentice Hall.

Becker, G. S. (1962). Investment in human capital: A theoretical analysis. Journal of political economy, 70(5, Part 2), 9-49. https://doi.org/10.1086/258724.

Becker, W., Bose, A., \& Freeman, V. (2015). An executive take on the top business trends: A McKinsey Global Survey., BE Magazine, 3(2), 60-61.

Betcherman, G. (1992). Are Canadian firms underinvesting in training? Canadian Business Economics, 1(1), 25-33.

Buckley, R., \& Caple, J. (2009). The theory and practice of training, $6^{\text {th }}$ Ed. London: British Library. 


\section{Macrothink}

International Journal of Human Resource Studies

ISSN 2162-3058

2018, Vol. 8, No. 2

Burgard, C., \& Göerlitz, K. (2011). Continuous training, job satisfaction and gender-an empirical analysis using German panel data, Ruhr Economic Paper No. 265. https://doi.org/10.2139/ssrn.1880937

Carrell, R. M., Kuzmits, F. E., \& Elbert, N. F. (1989). Personnel human resource Management, Columbus: Merrill Publishing Company.

Cascio, F. (1989). Managing human resources, $2^{\text {nd }}$ Edition, New York: McGraw Hill.

Chen, T. Y., Chang, P. L., \& Yeh, C. W. (2004). A study of career needs, career development programs, job satisfaction and the turnover intentions of R\&D personnel. Career development international, 9(4), 424-437. https://doi.org/10.1108/13620430410544364

Cole, G. A. (2002). Personal and human resource management, $5^{\text {th }}$ ed., Continuum London: York Publishers.

Commonwealth Network. (2017). Find Banking and Financial Services expertise in Lesotho, Available online

at http://www.commonwealthofnations.org/sectors-lesotho/business/banking_and_financial_ser vices/

Dabale, W. P., Jagero, N., \& Nyauchi, M. (2014). The relationship between training and employee performance: The case of Mutare city council, Zimbabwe. International Journal of Human Resource Studies, 4(4), 61-72. https://doi.org/10.5296/ijhrs.v4i4.6620

Daft, L. R. (2008). Management. $9^{\text {th }}$ ed. USA: South-Western Cengage Learning.

Deci, E. L., \& Ryan, R. M. (2000). The" what" and" why" of goal pursuits: Human needs and the self-determination of behavior. Psychological inquiry, 11(4), 227-268. http://dx.doi.org/10.1207/S15327965PLI1104_01

Dessler, G. (2008). Human resource management, $11^{\text {th }}$ ed., London: Pearson Education Limited.

Eleswed, M., \& Mohammed, F. (2013). The impact of gender, age, years of experience, education level, and position type on job satisfaction and organizational commitment: An exploratory study in the kingdom of Bahrain. International Journal of Business and Social Science, 4(11), 108-119.

Elnaga, A., \& Imran, A. (2013). The effect of training on employee performance. European Journal of Business and Management, 5(4), 137-147.

First National Bank Lesotho. (2017). First National Bank and FNB Lesotho Limited, Available online at https://www.fnb.co.ls/about/legal-about-us/index.html.

Gay, L. R. (1996). Educational research: competencies for analysis and application, Beverly Hill, CA: Sage Publications.

Ghauri, P., \& Grönhaug, K. (2005). Research Methods in Business Studies: A Practical Guide, $3^{\text {rd }}$ ed, London: Prentice Hall. 
Grant, A. M. (2008). Does intrinsic motivation fuel the prosocial fire? Motivational synergy in predicting persistence, performance, and productivity. Journal of applied psychology, 93(1), 48-58. https://doi.org/10.1037/0021-9010.93.1.48

Grobler, P. A., Warnich, S., Carrel, M. R., Elbert, N., \& Hatfield, R. D. (2002). Human resource management in South Africa, London: Thomson Learning.

Grund, C., \& Martin, J. (2012). Determinants of further training-evidence for Germany. The International Journal of Human Resource Management, 23(17), 3536-3558. https://doi.org/10.1080/09585192.2011.654347

Guay, F., Vallerand, R. J., \& Blanchard, C. (2000). On the assessment of situational intrinsic and extrinsic motivation: The Situational Motivation Scale (SIMS). Motivation and emotion, 24(3), 175-213. https://doi.org/10.1023/A:1005614228250

Guest, D. E. (1997). Human resource management and industrial relations. Journal of Management Studies, 24(5), 503-521. https://doi.org/10.1111/j.1467-6486.1987.tb00460.x

Hafeez, U., \& Akbar, W. (2015). Impact of training on employees' performance (evidence from pharmaceutical companies in Karachi, Pakistan). Business Management and Strategy, 6(1), 49-64. https://doi.org/10.5296/bms.v6i1.7804

Harrison, R. (2000). Employee development. Silver Lakes, Pretoria: Beekman Publishing.

Herbert, G. R., \& Doverspike, D. (1990). Performance appraisal in the training needs analysis process: a review and critique. Personnel Administration, 19(3), 253-270. https://doi.org/10.1177/009102609001900303

Ijigu, A. W. (2015). The effect of selected human resource management practices on employees' job satisfaction in Ethiopian public banks. Emerging Markets Journal, 5(1), 1-16. https://doi.org/10.5195/emaj.2015.64

Jacobs, R., \& Washington, C. (2003). Employee development and organizational performance: a review of literature and directions for future research. Human Resource Development International, 6(3), 343-354. https://doi.org/10.1080/13678860110096211

Khan, M. (2012). The impact of training and motivation on performance of employees. IBA Business Review, 7(2), 84-95.

Khoshnevis, H., \& Tahmasebi, A. (2016). The Motivation System in a Governmental Organization. Procedia-Social and Behavioral Sciences, 230,212-218. https://doi.org/10.1016/j.sbspro.2016.09.027

Kim, W. G.., Leong, J. K., \& Lee, Y. K. (2005). Effect of service orientation on job satisfaction, organizational commitment, and intention of leaving in a casual dining chain restaurant. International Journal of Hospitality Management, 24(2), 171-193. https://doi.org/10.1016/j.ijhm.2004.05.004

Kinicki, A., \& Kreitner, R. (2007), Employee behavior, McGraw-Hill, New York, NY. 
Kiweewa, S. B., \& Asiimwe, S. B. (2014). Does training influence employee performance in regulatory organizations in Uganda? Empirical evidence from UCC. Merit Research Journal of Business and Management, 2(2), 21-29.

Kotler, P., \& Armstrong, G. (2002). Marketing: an introduction. $6^{\text {th }}$ ed., London: Prentice-Hall.

Lesotho Post Bank. (2017). Overview of Lesotho Post Bank, Available online at http://www.lpb.co.ls/website1/overview.

Lipsey, R. G. (1989). Introduction to positive economics, $7^{\text {th }}$ ed., London: Weindnfeld and Nicholson.

Lyons, P. (2009). Team training for creating performance templates. Team Performance Management: An International Journal, 15(5/6), 257-275. https://doi.org/10.1108/13527590910983521

Nabi, M. N., Islam, M., Dip, T. M., \& Hassain, A. A. (2017). Impact of motivation on employee performances: a case study of Karmasangsthan bank Limited, Bangladesh. International Journal of Business and Management, 5(4), 57-78.

Nan, L. (2014). Research on employee training of state-owned commercial banks - industrial and commercial Bank of China as an example, International Journal of Business and Social Science, 5(6), 177-184.

Nassazi, A. (2013). Effects of Training on employee performance: evidence from Uganda, Thesis, University of Applied Sciences.

Nedbank Lesotho. (2017). Nedbank Lesotho History. Available online at http://www.nedbank.co.ls/our-history and http://www.nedbank.co.ls/about-nedbank-lesotho.

Noe, R. A. (2008). Employee training and development, $5^{\text {th }}$ ed., New York: McGraw-Hill.

Ocen, E., Francis, K., \& Angundaru, G. (2017). The role of training in building employee commitment: the mediating effect of job satisfaction. European Journal of Training and Development, 41(9), 742-757. https://doi.org/10.1108/EJTD-11-2016-0084

Omolo, P. A. (2015). Effect of motivation on employee performance of commercial banks in Kenya: A case study of Kenya Commercial Bank in Migori County. International journal of human resource studies, 5(2), 87-103. https://doi.org/10.5296/ijhrs.v5i2.7504

Owens, J. P. L. (2006). One more reason not to cut your training budget: The relationship between training and organizational outcomes. Public personnel management, 35(2), 163-172. https://doi.org/10.1177/009102600603500205.

Panagiotopoulos, G., \& Karanikola, Z. (2017), Training of human resource and job satisfaction, Global Journal of Human Resource Management, 5(7), 36-45.

Peteraf, M. A. (1993). The cornerstones of competitive advantage: a resource-based view. Strategic management journal, 14(3), 179-191. https://doi.org/10.1002/smj.4250140303 


\section{Mll Macrothink}

International Journal of Human Resource Studies

ISSN 2162-3058 2018, Vol. 8, No. 2

Pigors, P., \& Myers, A. C. (1989). Personnel administration: a point of view and method, 9th ed., New York: McGraw Hill Book Company.

Rowden, R. W., \& Conine, J. C. T. (2005). The impact of workplace learning on job satisfaction in small US commercial banks. Journal of workplace Learning, 17(4), 215-230. https://doi.org/10.1108/13665620510597176.

Sahinidis, A. G., \& Bouris, J. (2008). Employee perceived training effectiveness relationship to employee attitudes. Journal of European Industrial Training, 32(1), 63-76. https://doi.org/10.1108/03090590810846575

Sajuyigbe, A. S., \& Amusat, W. A. (2012). Staff training and development as managerial tools for organizational effectiveness: an appraisal of First Bank, JABU International Journal of Social and Management Sciences, 4(1), 100-109.

Shahzadi, I., Javed, A., Pirzada, S. S., Nasreen, S., \& Khanam, F. (2014). Impact of employee motivation on employee performance. European Journal of Business and Management, 6(23), 159-166.

Siebern, T. F. (2005). Job quality in European labour markets, in Bazen, S., Lucifora, C. and Salverda, W. (Eds), job quality and employer behaviour, Palgrave Macmillan, Basingstoke, Hants, 31-66. https://doi.org/10.1057/9780230378643_3

Skaalvik, E. M., \& Skaalvik, S. (2011). Teacher job satisfaction and motivation to leave the teaching profession: Relations with school context, feeling of belonging, and emotional exhaustion. Teaching and teacher education, 27(6), 1029-1038. http://dx.doi.org/10.1016/j.tate.2011.04.001

Standard Lesotho Bank. (2017). Overview of Standard Lesotho Bank. Available online at http://www.standardlesothobank.co.ls/website1/overview.

Stavrinoudis, T., \& Psimoulis, M. (2015). The effect of employee-training on HRM performance in the hotels of Attica, University of the Aegean, Greece.

Stoner, J. A. F. (1996). Management, $6^{\text {th }}$ ed., Australia: Pearson Education.

Stoner, J. A. F., Freeman, E., \& Gilbert, D. A. (1995). Management, 6th ed. London: Prentice-Hall International.

Subari, S., \& Riady, H. (2015). Influence of training, competence and motivation on employee performance, doderated by internal communications. American Journal of Business and Management, 4(3), 133-145. https://doi.org/10.11634/216796061706678

Sultana, A., Irum, S., Ahmed, K., \& Mehmood, N. (2012). Impact of training on employee performance: A study of telecommunication sector in Pakistan. Interdisciplinary Journal of contemporary research in business, 4(6), 646-661.

Swanepoel, B. J. (2000). South African human resource management theory and practice, $4^{\text {th }}$ ed., South Africa: Juta and Co. Ltd. 
Swart, J., Mann, C., Brown, S., \& Price, A. (2005). Human resource development: strategy and tatics. Oxford: Elsevier Butterworth- Heinemann Publications.

Tahir, A., \& Sajjad, S. (2013). Assessing the Impact of Training on Employees' Performance in Commercial Banks in Urban Lahore. The Lahore Journal of Business, 2(1), 95-109.

Thomas, K. W. (2002). Intrinsic motivation at work: building energy and commitment, San Francisco: Berrett-Koehler Publishers, Inc.

Togia, A., Koustelios, A., \& Tsigilis, N. (2004). Job satisfaction among Greek academic librarians. Library \& Information Science Research, 26(3), 373-383. https://doi.org/10.1016/j.lisr.2004.01.004

Ubeda, G. M., Marco, L. B., Sabater, S. V., \& García, L. F. (2013). Does training influence organisational performance? Analysis of the Spanish hotel sector. European Journal of Training and Development, 37(4), 380-413. https://doi.org/10.1108/03090591311319780

Ugbomhe, U. O., Osagie, G. N., \& Egwu, U. E. (2016). Impact of Training and Development on Employee Performance in Selected Banks in Edo North Senatorial District, Nigeria, Indian Journal of Commerce \& Management Studies, 7(3), 48-55.

Uyimadu, S. O. (2005). Research methods and procedures, Benin City: Otaghughu Int.

Vansteenkiste, M., Lens, W., \& Deci, E. L. (2006). Intrinsic versus extrinsic goal contents in self-determination theory: Another look at the quality of academic motivation. Educational psychologist, 41(1), 19-31. https://doi.org/10.1207/s15326985ep4101_4.

Wade Publications CC. (2015). The Lesotho Review: An Overview of the Kingdom of Lesotho's Economy -2015 Edition. Available online at http://www.lesothoreview.com/financial-services-investment-2015.php.

Weil, A., \& Woodall, J. (2005). Human Resource Development in France: the corporate perspective, Journal of European Industrial Training, 29(7), 529-540, https://doi.org/10.1108/03090590510621036.

Wognum, A. A. M. (2001). Vertical integration of human resources development policy within companies. Human resource development international, 4(3), 407-421. https://doi.org/10.1080/13678860010006149

Wood, F., \& Sangster, A. (2002). Business accounting, I, $9^{\text {th }}$ ed., United Kingdom: Financial Times Management.

Wright, P. C., \& Geroy, G. D. (2010) Changing the mindset: the training myth and the need for world-class performance, The International Journal of Human Resource Management, 12(4), 586-600. https://doi.org /10.1080/09585190122342

Wright, T. A., \& Bonett, D. G. (2007). Job satisfaction and psychological Well-being as nonadditive Predictors of Workplace Turnover, Journal of Management, 33(2), 141-160.

Young, N. (2009), Understanding the research process and methods: an introduction to 
research methods. Las Vegas: Act Press.

Zlate, S., \& Cucui, G. (2015). Motivation and performance in higher education. Procedia-social and behavioral sciences, $180, \quad 468-476$. https://doi.org/10.1016/j.sbspro.2015.02.146

Zulkifli, I., \& Duasa, J. (2009). Determinants of training and its impact on firm's performance: evidence from Malaysia, The Indian Journal of Labour Economics, 52(3), 433-447.

\section{Appendix}

Questionnaire for the Study on "The Impact of Training on Employees Performance: The Case of Banking Sector in Lesotho"

Introduction

We would like to undertake the study on "The Impact of Training on Employees Performance: The Case of Banking Sector in Lesotho". Therefore, we would like to humbly ask you to take a few minutes out of your busy schedule to answer this questionnaire. We promise you that your responses to the questions raised in the questionnaire will be treated with strict confidentiality and will be used only for the purposes of this research.

\section{Structure of the Questionnaire}

This questionnaire consists of two parts. The Part I consists of demographic information and Part II dwells on questions on the main research questions.

\section{Part I: Demographic information of the respondent}

1. Gender
a) Female
b) Male

2. Age
a) $18-25$
b) $26-35$
c) $36-45$
d) $46-55$
e) $56-59$

3. Marital status
a) Single
b) Married
c) Divorced
d) Widowed
e) Separated

4. Department:

5. Job Designation:

6. Rank

7. Highest Educational Qualification: 
8. How long have you worked for the organization? Years

9. Income level
(a) M1,000 - M5,000
(b) M6,000 - M10,000
(c) M11,000 - M20,000
(d) M21,000-M30,000
(e) M31,000 and above

\section{Part II Main Research Questions}

10. Have you had any form of training since you joined the organization?
a) Yes
b) No

If "yes" to the question above, please continue with the question below.

11. How were you selected for training?
a) On joining the company
b) Supervisors recommendation
c) Compulsory for all employees [ ]
d) Upon employee request [ ]
e) Performance appraisal

12. How often do you undergo training?
a) Quarterly
b) Every six months
c) Once a year
d) Every two years
e) No specific schedule.

13. What are the methods of facilitation at the training you have attended?
a) Lecture
b) Demonstrations
c) Discussions
d) Presentation
e) Seminar

14. What are your key responsibilities within the bank?

15. What are the prerequisite competencies and skills required in order to perform your responsibilities?

16. What training have you attended recently in your organization?

17. What was the purpose of the training? 
18. How did the training affect your ability to discharge your duties and responsibilities within the organization?

19. Before you attended, which aspects of your job were you not able to perform well?

20. What benefits do you obtain from participating in your bank's training program?

21. To what extent did the training impact on your job motivation?
(a) No positive impact
(b) Slight positive impact
(c) Moderate positive impact [ ]
(d) High positive impact [ ]
(e) Very high positive impact [ ]

22. To what extent did the training impact on your job satisfaction?

(a) No positive impact

(b) Slight positive impact

(c) Moderate positive impact

(d) High positive impact

(e) Very high positive impact

23. What problems do you face with regard to training and development within your organization?

24. Please specify any ways you think training and development in your organization can be improved

Thank you for your response

\section{Copyright Disclaimer}

Copyright for this article is retained by the author(s), with first publication rights granted to the journal.

This is an open-access article distributed under the terms and conditions of the Creative Commons Attribution license (http://creativecommons.org/licenses/by/4.0/). 